\title{
Popularisers, Interpreters, Advocates, Managers and Critics
}

\author{
Framing Science and Scientists in the Media
}

\author{
ESA VÄLIVERRONEN
}

Science journalism and - more broadly - science in the media has often been defined in terms of popularisation and diffusion of scientific knowledge. Science journalism is about translating scientific knowledge to lay audiences and about the public role of scientists as popularisers, educators or experts. According to this view media coverage of science is often defined and studied in terms of 'inaccuracy', 'distortion', 'miscommunication' or 'bias'.

This approach has produced some interesting results, but it also has some obvious limits. The main focus of the approach has been on the content of science, not so much on the role of science as social activity or an expert institution in society. However, scientists have multiple roles as experts in public discourse. They can act - or they are represented by the media - as expert witnesses, authoritative commentators, advisers, advocates of pressure groups or promoters of science. This means that science journalism is not only about information but also about science as social activity, the public legitimation of science and the role of scientists as experts.

This critique of the popularisation paradigm has been well documented by many sociologists of science and media scholars (e.g. Bucchi 1998; Dornan 1990; Hilgartner 1990; Hansen 1991; Lewenstein 1992; Whitley \& Shinn 1985; Väliverronen 1993) and shall therefore not be discussed here. It is more interesting to note that there have been rather few attempts at a more systematic analysis of the different roles of science and scientists as expert sources in media discourse.

Dep. of Communication, University of Helsinki, P.O. Box 54, FIN-00014 Helsinki, esa.valiverronen@helsinki.fi
In this article I wish to present one such attempt. Leaning on a case study of environmental reporting, I have identified five different media frames: popularisation, social problem, policy/politics, legitimation and science criticism; and respective roles for scientists as experts in public discourse: populariser, interpreter, adviser/advocate, promoter/manager and critic. The analysis is based on a study of the newspaper coverage of the forest damage issue in four Finnish newspapers between 1989 and 1995 and on interviews with scientists and journalists. I hope that the analysis also sheds light on some general features of public discourse on science and the environment.

\section{Science and Environmental Issues in the Media}

Science has become an increasingly public business. More and more often now, research projects are reviewed and scrutinized not only within but also outside scientific communities. This is not only about popularising research results. Questions are also asked in the media as to what is new, what is useful and important research, what sort of research needs to have funding. The mass media have become an arena for the legitimation of science and a forum mediating the relations between science and the rest of society (Felt \& Nowotny 1993, Väliverronen 1993 and 1998). The public image of science and popular interpretations may also influence science itself, for instance its choices of research subjects and areas in which it wants to invest its monies.

From the peace and seclusion of its ivory tower, science has been thrown into the middle of struggles for social prestige and resources. The public 
expectations placed on science are quite varied and often contradictory. These different roles and uses of science are perhaps most clearly visible when the media debate is about different kinds of social problems. Scientists may play an important role in the definition of social problems, not only in their capacity as producers of information but also as interpreters, witnesses, instigators of social movement, 'moral entrepreneurs' or authorities to which the contending parties can refer.

Environmental issues are one example of a social problem in the definition of which science and scientists have an exceptionally important role (Sundqvist 1991; Yearley 1991; Zehr 1994). The role of science is particularly important in two respects. On the one hand the identification of the symptoms and causes of environmental change is closely tied up with scientific knowledge. Science makes environmental problems visible and identifiable. Good examples are provided by such problems as ozone depletion and climate change. The only way to identify the environmental changes that lie behind these problems is by means of highly sophisticated technical equipment, advanced scientific theories and mathematical models.

On the other hand, the role of scientists is not confined to the perception and identification of environmental changes. Environmental problems must also be made socially visible. This is where politics and the media enter the scene: environmental problems must be brought into public debate and public consciousness so that steps can be taken to effect change. Scientists have indeed played an important part together with environmental movements in waking people up to hazards threatening them and the natural environment.

Thus science has become an increasingly important source of knowledge, argumentation and authority in the definition of environmental problems (Yearley 1991). Science produces knowledge and interpretations on which other environmental policy actors have to rely, to a lesser or greater extent. Having analysed environmental policy disputes in Germany and Britain in the 1980s, Christiane Barrier-Lynn (1991) concludes that in both countries scientists had a major influence on public opinion. In Germany, for instance, the debate on forest dieback was started by a handful of active scientists. Later on when the industry, environmental movements and the government joined the debate, they relied on their 'own' scientific experts. Thus the debate unfolded into an argument between experts and counter-experts.
As a consequence of these developments the role of science in the definition of environmental problems has often been disputed. This in turn has meant that science does not appear in the public debate on the environment only in the role of defining or resolving the problem, but it has itself become a public problem. The examples of acid rain, forest damage, ozone depletion and climate change concretely demonstrate how the authority of science and the credibility of scientists is called into question. This is also what happened in the Finnish debate on forest damage.

This article is based on a quantitative and qualitative textual analysis of the forest damage debate in four Finnish dailies, viz. Helsingin Sanomat (HS), Kaleva (Ka), Lapin Kansa (LK) and Pohjolan Sanomat (PS). Helsingin Sanomat is the biggest daily in Finland, the three others are regional papers published in northern Finland ${ }^{1}$

\section{Background: Acid Rain and Forest Dieback in Finland}

The public discussion on acid rain and forest damage started in Finland in the early 1980s as a reaction to the debate on 'Waldsterben' in Germany and Central Europe. However, the health of forests was not a cause of much public concern in Finland before 1988, in spite of the occasional warnings from some 'dissident' forest researchers. There then followed a dramatic change as newspapers began to talk about a 'state of emergency' in Finland's forests. At least the forests in Lapland seemed to be facing an 'ecological catastrophe'. The main threat was presented by two outmoded smelteries on the Russian Kola Peninsula, near the Finnish border. The change was rapid indeed: in 1987 there were hardly any problems, in 1989 it was a catastrophe.

The traditional slogan 'Finland lives from her forests' was reformulated as 'Finland lives from forest discussion'. One reason for the sudden change was that the leading Finnish forest authority, the Forest Research Institute (FFRI), which had previously strongly denied that Finnish forests were under any threat, now changed its mind. Another reason was that these new findings of forest damage in Lapland coincided with the big environmental boom in Europe and North America and the increasing reports of ozone depletion and climate change in the media.

One response to the threat on forests was the launch of a five-year multidisciplinary research 
project, The Lapland Forest Damage project in 1990. Public debate remained quite heated for a few years, and it can be compared to those in Germany or Austria (see e.g. Roqueplo 1985; Krott 1987) The debate was fuelled by the disagreement among forest researchers on the causes and seriousness of the damage. After 1993 the debate began to slow down and it came to a virtual standstill in 1995 when the Lapland Forest Damage Project published its final report. The main result was that the amount of pollution from the Kola smelteries in northern Finland was rather low and was not a serious threat to the nature in Lapland. The local forest damage found in Lapland in the late 1980s was explained mainly by reference to weather anomalies and traditional diseases such as those caused by Gemniella abietina.

Forest damage was perhaps the most widely debated environmental issue in Finland in the early 1990s. It became a symbol of environmental change in general and reflected the growing and increasingly controversial role of science and scientists in the media.

\section{Framing Science and Scientists in the Media}

Hans-Peter Peters (1994) has identified two different ways of dealing with science and research results in journalism. From a science-centred point of view the task of journalism is to convey to the general public information about research results in as accurate, understandable and interesting way as possible. The scientist's job is to popularise science and to enlighten the audience. From a problem-centred point of view, the focal concern is with social problems such as the health hazards of smoking, alcohol problems or environmental risks which need to be defined, controlled or resolved. The vantage-point within this approach is not science itself, but the focal concern is with different kinds of social phenomena and problems on which representatives of science (among other actors) present their interpretations. The science-centred approach has been typical of the journalistic genre known as science journalism, which has drifted apart from the rest of the journalistic field into separate media (popular science magazines) or separate sections or programme types (science pages, science programmes). By contrast, other genres of journalism such as news reporting or political reporting often deal with science from a broader social perspective.

By framing environmental problems in different ways, journalism offers its readers different ways in which to analyse and understand reality. In journalistic presentations the frame is the organising idea with which journalists interpret a certain event or phenomenon. In this sense the frame directs both thinking and action. Frames are "largely unspoken and and unacknowledged" (Gitlin 1980, 7); they are "mental maps" (Dunwoody \& Griffin 1993, 24) on the basis of which journalists create news and other stories.

Framing provides the media with an important tool that helps them organise individual events and broader phenomena into understandable entities with their own causes and consequences (Gamson $\&$ Lasch 1983). It also sets the boundaries within which the event or phenomenon can be discussed at each moment in time. For example, social issues are often framed in terms of disputes and disagreements. This kind of frame produces a setting of forand-against, with the parties to the discussion thrown on opposite sides of the fence, regardless of whether they want this or not.

As for the scientists who appear in journalism, the meaning of frames is that they offer them different kinds of actor or expert roles to which they have to adapt. On the other hand scientists will also try to choose different roles for their appearances on public and political arenas. These choices are based on scientists' views on the nature of science or on the relationship between science, politics and the media. Scientists who apply the narrow expert strategy will closely adhere to their own work or to questions that pertain to their own field of study. Those adopting an expansive strategy will also take a stand on issues that lie beyond their area of specialisation (Sundqvist 1991, 148-149). By taking part in public debate, scientists will try to influence 'public opinion' or political decision-makers directly.

In Finland scientists had a dominant role in the debate that was waged on the forest damage issue (Table 1). There were many reasons for this. First of all the debate in Finland followed the typical pattern of a 'risk debate' (Wiedemann 1991) in which the instigation comes from scientists and dissident members of the science community in particular. Secondly, disagreement about the causes of the damage and about the severity of the problem encouraged forest researchers to take an active part in the exchanges. Many earlier disputes in Finnish forest research also resurfaced with this disagreement. These ongoing disputes heightened the interest of the media and gave them a good reason to interview scientists. A third, more structural reason is the dependence of the media on experts as 
sources of information and authority. This is the case most typically in the case of defining environmental problems.

Table 1. Primary Definers of the Forest Damage Issue

\begin{tabular}{lrr} 
& N & $\%$ \\
\hline Scientists & 62 & 60 \\
Government officials & 22 & 21 \\
Forest owners & 7 & 7 \\
Politicians & 6 & 6 \\
Environmentalists & 2 & 2 \\
Industry representatives & 1 & 1 \\
Citizens & 1 & 1 \\
Other & 2 & 2 \\
\hline Total & 103 & 100
\end{tabular}

However, the dominant role of scientists cannot be explained away by reference to the nature of the forest damage problem. Forest damage is not only a scientific but also a broader ecological, economic and environmental policy problem. The material for this analysis comprised all articles which dealt in one way or another with the forest damage in Lapland. The result differs clearly from earlier German and Austrian studies dealing with the forest damage problem in journalism (Krott 1987; Krämer \& Suda 1987; Ochsenhofer 1993), which concluded that the role of researchers was not nearly as dominant. The forest economy, industry and environmentalists played a greater role in Germany and Austria than they did in Finland. ${ }^{2}$

In my material I have identified five frames which describe the different ways in which newspapers deal with science and research results (Table 2): these are the frames of popularisation, social problems, (environmental) policy, legitimation and science criticism. Each frame gives a somewhat different picture of science and scientists as experts of the forest damage problem. They provide scientists with the opportunity to take part in the debate either in the role of populariser, interpreter, adviser and advocate, manager and promoter or critic.

From a science point of view the three former scientist roles can be placed on the same continuum with the opposite poles represented by narrow and broad expert strategy. These describe the ways in which scientists take part in the debate on the state of forests and the environment. By contrast, the fourth and fifth role refer to how scientists talk about the state of science, i.e. the inter- pretation of research results and methods or the funding and organisation of research.

Within the frame of popularisation, newspapers presented the results of some recent or ongoing study. The scientist's role was confined to introducing the results: he or she took no (explicit) stand on the significance of the results or on how they could be used. Popularisation stories revolved closely around science and research results.

\section{Needle cast increased in northern Finland \\ (LK 8 November 1989) \\ Kola emissions exceed critical load \\ (Ka 6 July 1991) \\ Confirmed by research: Lapland has clean air (LK 21 August 1991)}

Within the social problem frame, the aim was to provide a scientifically sound interpretation or explanation for the forest damage problem or related concrete phenomena or observations. This was done not so much by laying down new facts, but mainly by producing information that would help people orientate to the problem and interpret what was happening. There existed no set, scientifically validated answer for this purpose, but scientists were to comment on new phenomena such as the yellowing of conifer needles, the sudden death of trees or other local phenomena in the light of their earlier knowledge and experience. This was the starting-point especially in the early stages of the debate when there was still very little research knowledge available on the state of the forests in Lapland.

\section{International forest researchers: Forest damage in western Lapland caused by natural conditions (HS 7 August 1992) \\ German scientists: Forest damage in Lapland caused by pollution from Central Europe (HS 8 August 1992)}

Within the frame of environmental policy, the phenomenon was set within a broader social context where the causes and possible solutions to the problem were discussed. This provided the scientist with the opportunity to take on an expanded expert role. In this frame some scientists appeared in the capacity of experts of forestry or environmental policy, giving advice to forest owners, government officials, politicians or the forest industry. Others adopted the role of advocates, criticising the government's environmental policy or forest policy. Whereas the scientist who sticks to the role of 
populariser usually draws a clear line between science and politics/policy, that boundary line is less clear in the role of advocate.

\section{Government must intervene in forest damage (LK 27 February 1989) \\ Growing calls to save the forests of Lapland ( $\mathrm{Ka}$ 15 February 1990)}

Within the frame of legitimation, the concern was with the status of science, i.e. research funding, organisation and social legitimation. Especially during the early stages of the debate on forest damage, some scientists campaigned actively for new air pollution measurement stations and for new research projects to be set up. These campaigns were indeed successful. Several new measurement stations were set up in Lapland and the Ministry of Agriculture and Forestry decided to spend FIM 30 million on a new five-year research programme. In addition, scientists were called upon to render public accounts of what they were doing, i.e. to introduce their ongoing research projects. In the media scientists appeared as advocates of science and as science politicians, calling for more money to be invested in research, or as managers whose job it was to respond to the questions of inquisitive journalists about the progress of their research work and to explain how they were using taxpayers' monies, even though they did not yet have any real research results to talk about.

A good indication of this is that one-third of the newspaper articles in my data dealt primarily with the state of research - funding problems, disagreements among individual scientists, etc. - rather than with the state of forests and the environment.

The Lapland Forest Damage Project was a unique research programme in the sense that the media followed its progress almost on a weekly basis. One reason for this public scrutiny was that scientists had been widely blamed during the early stages of the forest damage debate for belittling the problem and later for exaggerating the problem.

Lack of money serious threat to forest researchers (Ka 3 February 1990)

\section{Forest damage project set to start in spite of} funding problems (HS 4 February 1990)

The rarest form of journalism about science (which admittedly has become more common in recent years) is the interpretation, review and criticism of research results. In the case of forest damage there was an obvious need for this because the results presented by scientists were contradictory - or at least that was the impression they conveyed. The frame of science criticism offered the scientist a role in which it was possible to refute or reinterpret the results of other scientists or to criticise the methods they had used. Whereas in the legitimation frame journalism dealt in general terms with the state of research, its credibility and legitimation, the focus in the science criticism frame was on individual research results and their interpretation as well as scientists' differing interpretations about the causes and seriousness of the problem.

\section{Forest damage in Lapland not as extensive as suggested (HS 23 July 1991)}

\section{Nature does not obey the law of averages (LK 3 April 1992)}

The newspapers reviewed dealt with the forest damage problem in Lapland most often within the social problem frame $(31 \%)$. The second most popular frame was that of legitimation (26\%) followed by the frame of popularisation $(25 \%)$. The environmental policy and the science criticism frames were primary in 9 per cent of the stories. ${ }^{3}$

\section{Table 2. Representations of Science and Roles of Scientists}

\begin{tabular}{|c|c|c|}
\hline Frame & Functions & Roles for scientists \\
\hline Popularisation & $\begin{array}{l}\text { Presenting new } \\
\text { research results }\end{array}$ & Populariser \\
\hline Social problem & $\begin{array}{l}\text { Interpreting new } \\
\text { phenomena and } \\
\text { problems }\end{array}$ & Interpreter \\
\hline $\begin{array}{l}\text { (Environmental) } \\
\text { policy/politics }\end{array}$ & $\begin{array}{l}\text { Making and } \\
\text { commenting } \\
\text { policy claims }\end{array}$ & $\begin{array}{l}\text { Adviser } \\
\text { Advocate }\end{array}$ \\
\hline \multirow[t]{2}{*}{ Legitimation } & $\begin{array}{l}\text { Raising funds } \\
\text { or promoting } \\
\text { research }\end{array}$ & Promoter \\
\hline & $\begin{array}{l}\text { Rendering account } \\
\text { for use of public } \\
\text { funds }\end{array}$ & Manager \\
\hline $\begin{array}{l}\text { Science } \\
\text { criticism }\end{array}$ & $\begin{array}{l}\text { Commenting on } \\
\text { research results }\end{array}$ & Critic \\
\hline
\end{tabular}

These frames also reflected different conceptions of science and different views on the role of scientists as experts. Within the popularisation frame the scientists appeared in the role of impartial information producer and mediator. No questions were raised with regard to the certainty or reliability of the information presented because it was assumed that this had been ascertained by the science community itself with its internal quality control proce- 
dures. Almost without exception the information was presented as solid fact, without any reservations related to the research methods or the generalizability of the results.

Within the social problem frame the scientist usually appeared in the capacity of an impartial adviser: the scientist's job was to enlighten the people and 'public opinion'. However, journalism had a more active role than in popularisation: the aim was to embed the phenomenon and interpretations of that phenomenon in a broader social context. Compared with the frame of popularisation, a greater proportion of the stories were based on interviews with or the views of more than one scientist. Interestingly, however, these preliminary interpretations by scientists were presented in the media as hard, indisputable facts. This was a cause of much confusion because in some cases the scientists' views were almost diametrically opposed to each other. That scientists' opinions were presented as hard facts was not only the fault of the media and journalists, however. Some of the scientists themselves presented their interpretations as absolute certainties because the media had become the scene for their own internal disputes.

\section{Scientists' Views on Roles}

In my interviews with scientists I asked them which of the above roles they felt most comfortable with. Most of them chose a combination of two or three roles. The majority slotted themselves into the role of interpreter. The roles of populariser, advocate and critic were more or less equally popular. No one regarded themselves merely as a populariser of their research results. The role with which the scientists felt least comfortable was clearly that of manager or science promoter: only one of them said they were required in their position to promote science or to market their research results:

$$
\begin{aligned}
& \text { Populariser-no I'm definitely not as limited as } \\
& \text { that (researcher 7) } \\
& \text { Well I would say it's important for the } \\
& \text { researcher to be involved, but of course not very } \\
& \text { many are all that enthusiastic. (researcher 6) } \\
& \text { I suppose I could mainly belong to category } \\
& \text { one-two or then category five... Perhaps mainly } \\
& \text { category two, wasn't that the role of interpreter } \\
& \text { or something. (researcher } 4 \text { ) }
\end{aligned}
$$

The two groups of scientists who differed from each other most were those who did not make a clear distinction between the narrow and broad ex- pert strategy (from populariser to advocate) and, on the other hand, those who underlined this difference. The former described themselves as interpreter-advocates, the latter either as popularisercritics or interpreter-critics.

I also asked the scientists whether they felt they were free to appear in the role they wanted or whether they had to take on the role in which the media wanted to see them. There were very few complaints in this regard, although some researchers did say there had been instances where they thought that a role had been imposed on them from the outside.

There are at least two ways in which the positive responses can be interpreted. Firstly, the responses may indicate that scientists have much control over the sort of role in which they appear in public. Another possible interpretation is that the interviewees were more accustomed than most scientists to appearing in the media; they knew how the media worked and they knew what sort of attitude they would need to take.

\section{The Public Accountability of Science}

In this paper I have wanted to demonstrate that journalism offers many different roles to science as well as scientists. These roles are bound up both with the different ways in which the media frame environmental problems and with the expert strategies adopted by scientists.

As regards the relationship between science and the media, the most interesting new features are to be found within what I have described as the frames of legitimation and science criticism. The media produced a role for scientists in which they had to explain to taxpayers what they were doing. Journalists went to see scientists and asked them how they had organised their studies, what sort of methods and equipment were they using, when could they expect to see results. This new form of journalism is closely bound up with the idea of the public accountability of science (Felt \& Nowotny 1992 and 1993). Since science is funded out of the public purse and since it is expected to produce more and more results with practical applicability, scientists have to explain to the public what sort of progress they have made. In this sense the media have taken on board part of the role that traditionally has belonged to those funding research (Väliverronen 1993 and 1996).

In our case of forest damage in Lapland, there were also quite practical reasons for this kind of 'accountability journalism'. By Finnish standards 
the research project was a huge undertaking, involving four universities, five research institutes and some 50 scholars. Its budget was in excess of FIM 30 million. It was perhaps the first research project in Finland that the general public could follow virtually on a weekly basis. Once the forest damage in Lapland had become a major environmental threat, the media followed the progress of research very closely. Since the researchers involved did not always have new results to report or they had become more cautious in their interpretations, they preferred to talk to journalists about their research programmes rather than their preliminary results.

The mass-mediated public sphere has become an important arena for the legitimation of science. The institution of science has, at least to some extent, become dependent on the images and discourses produced and circulated in the mass media. Ongoing discussions on the public accountability of science or its public image are reflections of this development. It seems that scientific organisations have become increasingly worried about the media coverage.

The art of managing visibility is also becoming a daily routine for scientists working in different fields and institutional locations. Universities, departments and research institutes arrange courses for researchers on how to write popular papers, how to prepare a press release or how to appear on television. Although ten seconds in prime time news is not perhaps better than one peer-reviewed article in a scientific ranking, some might argue that that the old slogan 'publish or perish' has transformed into 'be seen in public or perish' (Väliverronen 1993).

The scientists I interviewed agreed that publicity had an important role to play particularly as far as research funding was concerned. Some went so far as to describe publicity as the "lifeblood" of research funding, some just stressed that it was important. Publicity has its pros and cons, but it has become an "integral part of the system".

\footnotetext{
Well yes you could even say that publicity is the lifeblood of environmental research... I mean if the media did not constantly raise hell about these things then it's hard to imagine how society would allocate its resources into these studies. (researcher 1)

In general terms it's no doubt useful and probably at the private level as well, but you have to be careful with this because it may also turn against you. (researcher 4)
}

It's a useful tool, you can use it either to raise your own profile or to throw mud on someone else's. In the autumn before they hand out the money you can criticise the work that others have been doing and praise your own. (researcher 8)

The important role of the mass media is recognised in a number of studies. Scientists themselves are also well aware of the instrumental role of the media and publicity (e.g. Dunwoody \& Ryan 1985; Peters 1995). The Lapland Forest Damage Project concludes in its final report that the "the good and abundant publicity received by the project in the media made it easier to secure its funding" (Tikkanen 1995, 12).

Another reason why scientists took such an active role in legitimising their work was that the credibility of forest research had been publicly called into question. The Forest Research Institute and forest researchers had to try and polish up their reputation. Scientists are generally quite reluctant to assess the results or views of their colleagues in the mass media. This reservedness is explained by the tendency of both scientists and other professions to try and keep any disputes they may have within the profession or discipline, because any public spillover might tarnish its public image (Larson 1990, 39). In the case of the forest damage issue it was impossible to avoid this. Given the obvious contradictions between different sets of research results and their different interpretations, these questions had to be brought out into the open. In the news stories this was relatively rare, but in leaders quite common.

Media representation may have a significant impact on the funding and public legitimation of science. This new role of communication and the mass media for science is linked to the changes in knowledge production, discussed for instance as a shift from mode 1 to mode 2 in the production of knowledge (Gibbons et al. 1994), or from normal discipline-based science to transdisciplinary, 'postnormal' science (Funtowitz and Ravetz 1993). These changes include a weakening of the peer review process and, in some cases, the so-called extended peer review in order to involve more participants in deciding what is socially accountable research.

However, this is perhaps evident only in certain areas of scientific research, for example in those that have strong commercial connections such as medical research or policy-relevant areas such as environmental research (Weingart 1998). The links 
between science and the media are also at their most intensive in areas with close connections to commercial, administrative and political applications as well as in those involving politically and morally sensitive issues. Good examples of this kind of research are provided by the field of energy production (such as cold fusion, high-temperature superconductivity and nuclear energy), environmental research (such as acid rain and forest dieback, climate change and biodiversity) and many fields of biomedicine, most notably genetic engineering.

In these areas the media have become an 'obligatory passage point' (Latour 1988) for scientists and administrators or companies funding their research. But it is perhaps not immediately clear who is 'enrolling' whom. In the current diversified media system with its numerous channels it very difficult to control publicity.

It also seems that the media and journalists are increasingly aware of the ways in which they are used for instrumental purposes. As this case shows, the journalists were not content simply to report on the research results obtained, but they also evaluated the social role of science and the implications of its results.

The role of the media was most active of all within the frames of environmental policy, legitimation and science criticism. The framing of forest damage as a political issue meant that some scientists were presented as representatives or certain

\section{Notes}

1. The textual corpus was collected in two phases. First, we collected all the stories published in Lapin Kansa, a newspaper that is published in Rovaniemi (the biggest town in Lapland) and that covered the issue more intensively, between January 1989 and March 1993. On the basis of these data we gathered another corpus, which consists of the most intensive periods of the forest damage debate (November 1989, February 1990, July 1991 and August 1992). This corpus which runs up to 104 news stories, forms the basis of the analysis presented in this paper. In addition, we gathered, more selectively, newspaper articles from these as well as other newspapers and periodicals between 1980 and 1995. To complement this textual analysis, we interviewed 8 scientists and 4 journalists, who were schools of thought or as advocates of certain parties. Since the mass media were inclined at one stage to dramatise and personify the disagreements between scientists, it was by no means always possible for the scientists to remain in the role of an impartial adviser. The media used experts selectively, opting wherever possible to speak to scientists whose views best upheld the dramatic tension of the discussion (cf. Peters 1994, 171-179).

Within the science criticism frame research results were interpreted and commented on from two directions. On the one hand scientists commented on the results of their colleagues and explained the problems related to the extent and representativity of their research material or the validity of their research methods. Journalists, for their part, interpreted the differences between research results from a political perspective by referring to scientists' different backgrounds and interests. Both these approaches called into question the ideal-type image of science according to which there is no need to debate the validity of research results or the conditions for their production outside the scientific community.

Compared to traditional science journalism, the media adopted an active role in reporting science as part of social and political struggles. The forest damage debate revealed increasing public scepticism towards the supposed neutral role of science and scientists in solving social problems and called for a new kind of reflexivity in science reporting. actively engaged in the forest damage debate. These interviews were carried out during spring 1995.

2. These studies are not directly comparable. The study by Ochsenhofer (1993) on forest damage in Austrian newspapers is perhaps the closest comparison. Ochsenhofer studied the appearance of different types of actors in newspaper articles. The biggest single group was represented by scientists, accounting for one-third of all appearances. Politicians accounted for onequarter. In the study by Krott $(1987,8)$ only one-tenth of the data concerning forest damage came directly from research sources.

3. Some of the newspaper stories contain elements from more than one frame. Likewise, scientists sometimes appeared in different roles. I have classified the newspaper articles on the basis of their primary frame. 


\section{References}

Barrier-Lynn, Christiane (1991) Scientifiques et acteurs environmentaux. Societes Contemporaines 6, Juin 1991.

Bucchi, Massimiano (1998) Science and the Media. London and New York: Routledge.

Dornan, Christopher (1990) Some Problems in Conceptualising the Issue 'Science in the Media'. Critical Studies in Mass Communication 7: 48-71.

Dunwoody, Sharon \& Ryan, Michael (1985) Scientific Barriers to the Popularization of Science in the Mass Media. Journal of Communication 35 (1).

Dunwoody, Sharon \& Griffin, Robert (1993) Journalistic Strategies for Reporting Long-Term Environmental Issues. In Hansen, Anders (ed.) The Mass Media and Environmental Issues. Leicester.

Evaluation (1992) Evaluation of Research in Forest Damage Caused by Air Impurities in Finland. The Academy of Finland. Helsinki: Vapk.

Felt, Ulrike \& Nowotny, Helga (1992) Striking Gold in the 1990s: The Discovery of High Temperature Superconductivity and its Impact on the Science System. Science, Technology and Human Values 17:4.

Felt, Ulrike \& Nowotny, Helga (1993) Science Meets the Public. Public Understanding of Science 2: 375-390.

Funtowitz, Silvio \& Ravetz, Jerome (1993) Science for the Postnormal Age. Futures 25 (1993):7.

Gamson, William \& Lasch, Kathryn (1983) The Political Culture of Welfare Policy. In Spiro, S.E. (ed.) Evaluating the Welfare State. New York: Academic Press.

Gibbons, Michael et al. (1994) The New Production of Knowledge. London: Sage.

Gitlin, Todd (1980) The Whole World is Watching. Berkeley: University of California Press.

Hansen, Anders (1991) The Media and the Social Construction of the Environment. Media, Culture and Society 13: 443-458.

Hilgartner, Stephen (1990) The Dominant View of Popularisation. Social Studies of Science 20: 519539.

Krott, Max (1987) Waldsterben zwischen Mythos und Medien. Forstarchiv 58 (1).

Krämer, Paul \& Suda, Michael (1987) Das Waldsterben in den Massenmedien. Allgemeine Forstzeitschrift 49/ 1987: 1291-1294.

Larson, Magali Sarfatti (1990) In the Matter of Experts and Professionals - Or How Impossible is it to Leave Nothing Unsaid. In Torstendahl, R. \& Burrage, M. (eds.) The Formation of Professions. London: Sage.
Latour, Bruno (1988) The Pasteurization of France. Cambridge and London: Harvard University Press.

Lewenstein, Bruce (1992) The Meaning of 'Public Understanding of Science' in the United States after World War II. Public Understanding of Science 1 (1).

Ochsenhofer, Dietmar (1993). Zeitungsberichterstattung über Wissenschaftliche Waldschadenforschung. Institut für forstliche Betriebswirtschaft und Forstwirtschaftspolitik an der Universität für Bodenkultur, Wien.

Peters, Hans-Peter (1994) Wissenshafliche Experten in der Öffentlichen Kommunikation über Technik, Umwelt und Risiken. Kölner Zeitschrift für Soziologie und Sozialpsychologie, Sonderheft 34, Öffentlichkeit, Öffentliche Meinung, Soziale Bewegungen.

Peters, Hans-Peter (1995) The Interaction of Journalists and Scientific Experts: Co-Operation and Conflict between Two Professional Cultures. Media, Culture \& Society 17: 31-48.

Roqueplo, Philippe (1986) Der saure Regen: ein "Unfall in Zeitlupe". Soziale Welt 37: 402-426.

Sundqvist, Göran (1991) Vetenskapen och miljöproblem. Göteborgs Universitet, Sociologiska Institutionen.

Tikkanen, Eero (1995) (toim.) Kuolan saastepäästöt Lapin metsien rasitteena. Itä-Lapin metsävaurioprojektin loppuraportti. Helsinki: Metsäntutkimuslaitos.

Weingart, Peter (1997) From "Finalization" to "Mode 2": Old Wine in New Bottles? Social Science Information 36 (1997): 4.

Whitley, Richard (1985) Knowledge Producers and Knowledge Acquirers. in Shinn, T. \& Whitley, R. (eds.) Expository Science. Dordrech: Reidel.

Wiedemann, Peter (1991) Strategien in der Risiko-Kommunikation und ihre Probleme. In Jungermann, Helmut et al. (eds.) Risikokontroversen. Berlin: Springer Verlag.

Väliverronen, Esa (1993) Science and the Media: Changing Relations. Science Studies 6 (2)

Väliverronen, Esa (1996) Ympäristöuhkan anatomia. Tiede, mediat ja metsän sairaskertomus. Tampere: Vastapaino.

Väliverronen, Esa (1998) Biodiversity and the Power of Metaphor in Environmental Discourse. Science Studies 11 (1999): 1.

Yearley, Steven (1991) The Green Case. London: Harper Collins.

Zehr, Stephen (1994) The Centrality of Scientists and the Translation of Interests in the U.S. Acid Rain Controversy. Canadian Review of Sociology and Anthropology 31 (3). 